\title{
Babesia vesperuginis in insectivorous bats from China
}

\author{
Hui-Ju Han ${ }^{1 \dagger}$, Jian-Wei Liu ${ }^{1 \dagger}$, Hong-Ling Wen², Xiang-Rong Qin', Min Zhao', Li-Jun Wang ${ }^{1}$, Chuan-Min Zhou', \\ Rui $\mathrm{Qi}^{1}, \mathrm{HaO} \mathrm{Yu}^{3}$ and Xue-Jie $\mathrm{Yu}^{1 *}$
}

\begin{abstract}
Background: To increase understanding of human bacterial and parasitic pathogens in bats, we investigated the prevalence of Babesia spp., Rickettsia spp., Anaplasma spp. and Coxiella burnetii in bats from China.

Methods: Bats were captured from Mengyin County, Shandong Province of China using nets. DNA was extracted from the blood and spleen of bats for molecular detection of Babesia spp., Rickettsia spp., Anaplasma spp. and Coxiella burnetii with specific primers for each species.

Results: A total of 146 spleen samples and 107 blood samples of insectivorous bats, which belonged to 6 species within two families, were collected from Mengyin County, Shandong Province of China. We found that two Eptesicus serotinus $(2 / 15,13.3 \%)$ were positive for Babesia vesperuginis. We were unable to detect genomic sequences for Rickettsia spp., Anaplasma spp. and Coxiella burnetii.

Conclusions: To our knowledge, our study showed for the first time the presence of Babesia vesperuginis in Eptesicus serotinus collected from China, suggesting that Babesia vesperuginis has a broad host species and geographical distribution.
\end{abstract}

Keywords: Bat, China, Babesia vesperuginis

\section{Background}

Bats have been studied in recent years due to their association with several serious emerging viruses, such as SARS-Coronavirus, Hendra virus, Nipha virus, Ebola virus and Marburg virus [1]. Most studies have focused on emerging viruses; however, bacterial and parasitic agents in bats have been largely neglected. We previously showed that bats from northern China carried several novel Bartonella spp. [2] as well as a diversity of pathogenic Leptospira spp. [3]. To have a better understanding of bacterial and parasitic pathogens in bats, we expanded our study to several tick-borne bacterial and parasitic pathogens, including Babesia spp., Rickettsia spp., Anaplasma spp. and Coxiella burnetii.

Babesia spp. are tick-transmitted protozoan hemoparasites associated with a wide range of vertebrate hosts worldwide [4]. So far, Babesia spp. detected in bats have

\footnotetext{
* Correspondence: yuxuejie@whu.edu.cn

${ }^{\dagger}$ Hui-Ju Han and Jian-Wei Liu contributed equally to this work.

${ }^{1}$ Wuhan University School of Health Sciences, Wuhan, Hubei, China

Full list of author information is available at the end of the article
}

been almost exclusively Babesia vesperuginis [5-9], with the exception of a study reporting Babesia canis, the causative agent of canine babesiosis, in the feces of bats from Hungary [10]. In addition, a recent study reported the detection of $B$. vesperuginis, Babesia crassa and $B$. canis in ixodid ticks on bats [11], which indicated that bats could harbor a greater diversity of Babesia species and hard ticks could also play a role in Babesia transmission among bats. The role of bats in the ecology of $\mathrm{Ba}$ besia spp. as well as the vectors involved in transmission of Babesia spp. among bats deserves further investigation.

Rickettsia spp. are intracellular bacteria that are responsible for life-threatening spotted and typhus fevers in humans [12]. So far, Rickettsia spp. infections in bats were limited to several serological and molecular surveys in America, Africa and Europe. Antibodies against several spotted fever group (SFG) Rickettsia spp. were reported in bats from Brazil and USA [13, 14]. DNA of Rickettsia spp. was also detected in the blood samples of bats from Swaziland, South Africa and Saint Kitts Island [15, 16]. A recent study conducted in Europe showed that Rickettsia

(c) The Author(s). 2018 Open Access This article is distributed under the terms of the Creative Commons Attribution 4.0 International License (http://creativecommons.org/licenses/by/4.0/), which permits unrestricted use, distribution, and 
spp. DNA was detected in bat feces [17]. Moreover, bat ectoparasites, including soft ticks (Argasidae), hard ticks (Ixodidae) and flies (Nycteribiidae), were found to carry a diversity of Rickettsia spp. that were identical to those found in bats, indicating the vector-borne transmission of Rickettsia spp. [18-23]. So far, there is a lack of knowledge on Rickettsia spp. in bats in Asia.

Anaplasma spp. belong to the order Rickettsiales, causing tick-borne anaplasmosis in animals and humans [24]. So far, there is no report of Anaplasma spp. in bats.

Coxiella burnetii is an obligate intracellular gram-negative bacterium, and is the agent of Q fever [25]. So far, there are no reports of $C$. burnetii in bats. However, its existence in ticks from bats has been reported in Algeria [26].

Therefore, the aim of the study was to investigate the prevalence of Babesia spp., Rickettsia spp., Anaplasma spp. and C. burnetii in bats from China.

\section{Methods}

\section{Bat sampling}

Bats were captured with nets from Mengyin County, Shandong Province of China $\left(117^{\circ} 45^{\prime}\right.$ to $118^{\circ} 15^{\prime} \mathrm{N}, 35^{\circ} 27^{\prime}$ to $\left.36^{\circ} 02^{\prime} \mathrm{S}\right)$ as part of an ongoing program of detecting novel microorganisms (viruses, bacteria and parasites) in bats. Identification of bat species was performed by DNA sequencing the PCR amplified cytochrome $b$ (cytb) gene as described previously [27]. Details on the collection of bat specimens are as described previously [2].
Briefly, bats were anesthetized for collecting blood samples, and were then killed with overdosed anesthetic to collect organs.

\section{Molecular detection for Babesia spp., Rickettsia spp., Anaplasma spp. and C. burnetii}

Bat blood DNA extraction was performed with the Qiagen DNA Kit (Qiagen, Hilden, Germany) and the spleen was extracted with the AllPrep DNA/RNA Mini Kit (Qiagen), according to the manufacturer's instructions. Blood DNA samples were screened for Babesia spp., Rickettsia spp. and Anaplasma spp. Spleen DNA samples were screened for C. burnetii. Primers used in this study are shown in Table 1.

For Babeisa spp., an initial screening PCR targeting $18 S$ rDNA was conducted in a $50 \mu \mathrm{l}$ mixture containing $25 \mu \mathrm{l}$ DreamTaq Green PCR Master Mix $(2 \times)$ (Thermo Fisher Scientific, Waltham, MA, USA), $0.8 \mu \mathrm{l}$ $25 \mu \mathrm{mol} / \mathrm{l}$ of each forward and reverse primer (Sangon Biotech, Shanghai, China), 16.4 $\mu$ l nuclease-free water, and $7 \mu \mathrm{l}$ blood DNA of each sample. Nuclease-free water was used as negative controls. PCR was performed under the following conditions: 1 denaturing cycle at $95^{\circ} \mathrm{C}$ for $5 \mathrm{~min}$ followed by 35 cycles at $95^{\circ} \mathrm{C}$ for $30 \mathrm{~s}, 55^{\circ} \mathrm{C}$ for $30 \mathrm{~s}$, and $72{ }^{\circ} \mathrm{C}$ for $1 \mathrm{~min}$ and an additional final cycle at $72{ }^{\circ} \mathrm{C}$ for $10 \mathrm{~min}$

For $18 S$ rDNA positive samples, an additional nested PCR targeting cox1was performed. The first round PCR

Table 1 PCR primers used for Babesia spp., Rickettsia spp. and Anaplasma spp. and C. burnetii screening

\begin{tabular}{|c|c|c|c|c|c|c|c|}
\hline Target agent & PCR method & Primer & Primer sequences $\left(5^{\prime} \rightarrow 3^{\prime}\right)$ & Target gene & Amplicon size (bp) & Tissue tested & Reference \\
\hline \multirow[t]{6}{*}{ Babesia spp. } & \multirow[t]{2}{*}{ PCR } & BJ1 & GTCTTGTAATTGGAATGATGG & \multirow[t]{2}{*}{185 rDNA } & \multirow[t]{2}{*}{$\sim 500$} & \multirow[t]{6}{*}{ Blood } & \multirow[t]{2}{*}{ [10] } \\
\hline & & BN2 & TAGTITATGGTTAGGACTACG & & & & \\
\hline & \multirow[t]{4}{*}{ Nested PCR } & Bab_For1 & ATWGGATTYTATATGAGTAT & \multirow[t]{4}{*}{$\operatorname{cox} 1$} & \multirow[t]{4}{*}{924} & & \multirow[t]{4}{*}{ [7] } \\
\hline & & Bab_Rev1 & ATAATCWGGWATYCTCCTTGG & & & & \\
\hline & & Bab_For2 & TCTCTWCATGGWITAATTATGATAT & & & & \\
\hline & & Bab_Rev2 & TAGCTCCAATTGAHARWACAAAGTG & & & & \\
\hline \multirow[t]{4}{*}{ Rickettsia spp. } & \multirow[t]{2}{*}{ qPCR } & gltA-F & GTGAATGAAAGATTACACTATTTAT & \multirow[t]{2}{*}{$g / t A$} & \multirow[t]{2}{*}{-} & \multirow[t]{4}{*}{ Blood } & \multirow[t]{4}{*}{ [30] } \\
\hline & & gltA-R & GTATCTTAGCAATCATTCTAATAGC & & & & \\
\hline & \multirow[t]{2}{*}{ qPCR } & $338-\mathrm{F}$ & GAMAAATGAATTATATACGCCGCAAA & \multirow[t]{2}{*}{ RC0338 gene } & \multirow[t]{2}{*}{-} & & \\
\hline & & $338-\mathrm{R}$ & ATTATTKCCAAATATTCGTCCTGTAC & & & & \\
\hline \multirow[t]{4}{*}{ Anaplasma spp. } & \multirow[t]{4}{*}{ Nested PCR } & AE1-F & AAGCTTAACACATGCAAGTCGAA & \multirow[t]{4}{*}{165 rRNA } & \multirow[t]{4}{*}{926} & \multirow[t]{4}{*}{ Blood } & \multirow[t]{4}{*}{ [31] } \\
\hline & & $A E 1-R$ & AGTCACTGACCCAACCTTAAATG & & & & \\
\hline & & EE3 & GTCGAACGGATTATTCTITATAGCTTGC & & & & \\
\hline & & EE4 & CCCTTCCGTTAAGAAGGATCTAATCTCC & & & & \\
\hline \multirow[t]{4}{*}{ Coxiella burnetii } & \multirow[t]{4}{*}{ Nested PCR } & omp1 & AGTAGAAGCATCCCAAGCATTG & \multirow[t]{4}{*}{ com 1} & \multirow[t]{4}{*}{438} & \multirow[t]{4}{*}{ Spleen } & \multirow[t]{4}{*}[32]{} \\
\hline & & omp2 & TGCCTGCTAGCTGTAACGATTG & & & & \\
\hline & & omp3 & GAAGCGCAACAAGAAGAACA & & & & \\
\hline & & omp4 & TGGAAGTTATCACGCAGTTG & & & & \\
\hline
\end{tabular}


was conducted in a $25 \mu \mathrm{l}$ mixture containing $0.125 \mu \mathrm{l}$ $5 \mathrm{U} / \mu \mathrm{l}$ TakaRa Ex Taq (TaKaRa, Shiga, Japan), $2.5 \mu \mathrm{l}$ $10 \times$ ExTaqbuffer $\left(\mathrm{Mg}^{2+}\right.$ free), $2 \mu \mathrm{l} 25 \mathrm{mM} \mathrm{MgCl} 2,2 \mu \mathrm{l}$ dNTP mixture ( $2.5 \mathrm{mM}$ for each), $0.4 \mu \mathrm{l} 25 \mu \mathrm{mol} / \mathrm{l}$ of each forward and reverse primer, $12.6 \mu \mathrm{l}$ nuclease-free water and $5 \mu \mathrm{l}$ blood DNA of each sample. The second round PCR was the same as described above for $18 S$ rDNA except that $3 \mu \mathrm{l}$ of first round PCR product was used as a template. The PCR condition was the same as described for $18 \mathrm{~S}$ rDNA, but the annealing temperature for the first and second rounds of PCR were $45{ }^{\circ} \mathrm{C}$ and $49{ }^{\circ} \mathrm{C}$, respectively.

For Anaplasma spp. and C. burnetii, a nested PCR was conducted as described for cox 1 of Babesia spp. Blood DNA and spleen DNA were used for the detection of Anaplasma spp. and C. burnetii, respectively. The PCR conditions were the same as described for $18 \mathrm{~S}$ rDNA of Babesia spp.

PCR products were analyzed by $1.2 \%$ agarose gel electrophoresis and detected using ethidium bromide under UV light. PCR products with expected sizes were excised from gels and extracted using a Gel Extraction Kit (Promega, Madison, WI, USA), which were then cloned into the pMD19-T vector (TaKaRa) for sequencing.

Quantitative real-time PCR (qPCR) was used for the detection of Rickettsia spp. The reaction was conducted in a $50 \mu \mathrm{l}$ mixture containing $25 \mu \mathrm{l}$ FastStart Universal SYBR Green Master (ROX), $0.8 \mu \mathrm{l} 25 \mu \mathrm{mol} / \mathrm{l}$ of each forward and reverse primer, $16.4 \mu \mathrm{l}$ nuclease-free water, and $7 \mu \mathrm{l}$ blood DNA of each sample. The tests were performed using a Light Cycler 480 II (Roche, Mannheim, Germany) with the following conditions: an initial denaturation at 95 ${ }^{\circ} \mathrm{C}$ for $10 \mathrm{~min}$, followed by 40 cycles at $95{ }^{\circ} \mathrm{C}$ for $10 \mathrm{~s}$ and at $58{ }^{\circ} \mathrm{C}$ for $30 \mathrm{~s}$. Nuclease-free water was used as negative controls in each run. Results were considered positive if the cycle threshold $(\mathrm{Ct})$ value was lower than 36 .

\section{Phylogenetic analysis}

Chromatograms were checked with Chromas 2.5.1 (Technelysium, Tewantin, QLD, Australia) to exclude double peaks, and sequences were analyzed with the BLAST programme (http://blast.ncbi.nlm.nih.gov/Blast.cgi).
After alignment by ClustalW with MEGA 7.0 [28], phylogenetic trees were constructed using the Maximum Likelihood method with the Tamura-Nei model by using MEGA7.0, and bootstrap values were calculated with 1000 replicates.

\section{Results}

A total of 146 bats belonging to 6 species within two families were sampled. Bats of the family Rhinolophidae included 4 Rhinolophus ferrumequinum and 14 Rhinolophus pusillus captured from a karst cave; bats of the family of Vespertilionidae included 26 Eptesicus serotinus from two farmers' houses, 34 Myotis fimbriatus and 10 Myotis ricketti from a city sewer and 58 Myotis pequinius from a cave (Table 2). Finally, 146 spleen DNA samples were screened for C. burnetii, and 107 blood DNA samples were screened for Babesia spp., Rickettsia spp. and Anaplasma spp.

In this study, we found that 2 out of 15 blood samples of E. serotinus $(2 / 15,13.3 \%)$ were positive for Babesia spp., while blood samples of the other 5 bat species $(R h$. ferrumequinum, Rh. pusillus, My. fimbriatus, My. ricketti and $M y$. pequiniu) were all negative. BLAST analysis of the $517 \mathrm{bp} 18 \mathrm{~S}$ rDNA sequences showed that the two Babesia spp. detected in E. serotinus in this study (designated as bat Babesia vesperuginis SD030 and bat Babesia vesperuginis SD043), which differed by 4 nucleotides, shared $99.4 \%$ similarity with $B$. vesperuginis (GenBank: AJ871610). BLAST analysis of the 924 bp cox 1 sequences showed that the bat Babesia vesperuginis SD030 and bat Babesia vesperuginis SD043 differed by 3 nucleotides, and shared $98.2 \%$ and $98.1 \%$ similarity with $B$. vesperuginis (GenBank: MF996533), respectively. Phylogenetic analysis of $18 \mathrm{~S}$ rDNA and cox1genes also showed that Babeisa spp. detected in bats in this study clustered together with $B$. vesperuginis (Figs. 1 and 2). The $18 S$ rDNA and cox 1 sequences of B.vesperuginis of this study were deposited in the GenBank with accession numbers: MG832414-MG832415 and MH234577-MH234578.

We were unable to detect genomic sequences for Rickettsia spp., Anaplasma spp. and C. burnetii.

Table 2 Information of bats sampled from Mengyin County, Shandong Province of China

\begin{tabular}{llllll}
\hline Family & Sampling site & Species & Common name & Spleen samples & Blood samples \\
\hline Rhinolophidae & Karst Cave & Rhinolophus ferrumequinum & Greater horseshoe bat & 4 & 3 \\
& & Rhinolo phuspusillus & Least horseshoe bat & 14 & 10 \\
Vespertilionidae & Farmers' houses & Eptesicus serotinus & Common serotine & 26 & 34 \\
& City sewer & Myotis fimbriatus & Fringed long-footed myotis & 34 & 15 \\
& & Myotis ricketti & Rickett's big-footed myotis & 10 & 58 \\
Total & Cave & Pyotis pequinius & & 146 & 58 \\
\hline
\end{tabular}




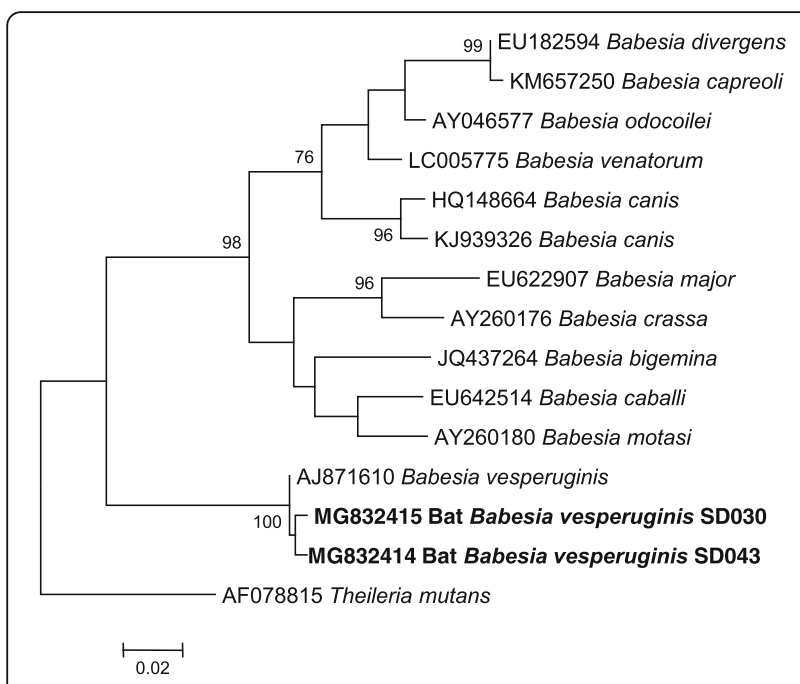

Fig. 1 Phylogenetic tree based on the 517 bp 185 rDNA sequences of Babesia spp. identified in this study and relevant sequences from GenBank. The tree was constructed with MEGA 7.0 by using the Maximum Likelihood method with the Tamura-Nei model. Only bootstrap values no lower than 75\% were shown. Babesia vesperuginis detected in bats in this study are shown in bold, and are designated as bat Babesia vesperuginis SD030 and bat Babesia vesperuginis SD043. Theileria mutans was used as the outgroup

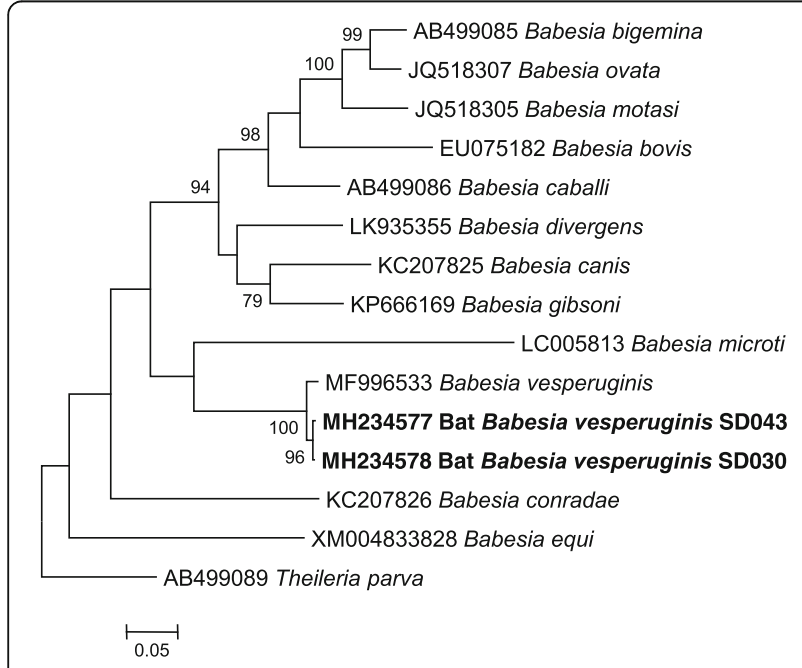

Fig. 2 Phylogenetic tree based on the 924 bp cox 1 sequences of Babesia spp. identified in this study and relevant sequences from the GenBank. The tree was constructed with MEGA 7.0 by using the Maximum Likelihood method with the Tamura-Nei model. Only bootstrap values no lower than 75\% were shown. Babesia vesperuginis detected in bats in this study are shown in bold, and are designated as bat Babesia vesperuginis SD030 and bat Babesia vesperuginis SD043. Theileria parva was used as the outgroup

\section{Discussion}

Babesia vesperuginis in bats was first described in bats from Italy, and later also found in bats from other parts of Europe (UK, Austria, Czech Republic, Romania) and South America (Colombia) [5, 7-9]. So far, B. vesperuginis has been detected in Nyctalus noctula and Pipistrellus sp. from Italy; My. mystacinus and Pipistrellus sp. from the UK; Mormoops megalophylla from Colombia; My. alcathoe, My. bechsteinii, My. myotis and Vespertilio murinus from Romania; Ny. noctula, Pi. nathusii and Pi. pipistrellus from the Czech Republic; Pi. pipistrellus and Ve. murinus from Austria; and Pi. pipistrellus from China [5-9]. The prevalence of $B$. vesperuginis in Pipistrellus spp. in Europe has been reported as $8.45 \%$ (6/71), 9.22\% (19/206), 16.7\% (6/36) and $10 \%(5 / 48)[6,7,9,29]$. The prevalence of $B$. vesperuginis in Mo. megalophylla in South America and in N. noctula in Europe was reported to be 1.19\% (2/168) and 1.63\% (4/246), respectively [5, 7]. However, the prevalence of $B$. vesperuginis in other bat species might be biased due to the limited sample size $[7,8]$. In this study, the prevalence of $B$. vesperuginis in E. serotinus from China was 13.3\% (2/15), which might also be biased by the limited sample size. To our knowledge, this is the first report of $B$. vesperuginis in $E$. serotinus, suggesting that $B$. vesperuginis has a broad host species and geographical distribution.

Natural and experimental infection showed that B.vesperuginis was pathogenic to bats, which could result in symptoms such as lowered blood haemoglobin, raised white blood cell counts and enlarged spleen in bats [8]. Soft ticks (Argas vespertilionis) were suspected to play a role in the transmission of $B$. vesperuginis among bats [8]. Although no ticks were found on bats in this study, a recent study reported that soft ticks (Argas vespertilionis) collected from $B$. vesperuginis-positive bats (Pi. pipistrellus) were also positive for $B$. vesperuginis in northwestern China [6], indicating that soft ticks might be the vector for $B$. vesperuginis transmission among bats.

\section{Conclusions}

We detected B. vesperuginis in E. serotinus collected from China, suggesting that $B$. vesperuginis has a broad host species and geographical distribution. Since $B$. vesperuginis is pathogenic to bats, the finding of this species in China has some implications for the conservation of bats in China.

\section{Acknowledgments}

We are grateful to Mengyin County Center for Disease Control and Prevention for their assistance in bat collection. China (No. 31570167). 


\section{Availability of data and materials}

The $B$. vesperuginis sequences of this study are available in the GenBank under the accession numbers MG832414-MG832415 and MH234577$\mathrm{MH} 234578$.

\section{Authors' contributions}

$\mathrm{HJH}$ designed the study. HJH, JWL, HLW, XRQ, MZ, LJW, CMZ and YLZ participated in bat sampling and performed the experiments. $\mathrm{HJH}$ and $\mathrm{RQ}$ helped in data analysis. HJH, XJY and HY wrote the manuscript. All authors read and approved the final manuscript.

\section{Ethical approval}

The collection of bats for microbiological studies was approved by the Ethics Committee of Prevention Medicine of Shandong University (No.20150501).

\section{Competing interests}

The authors declare that they have no competing interests.

\section{Publisher's Note}

Springer Nature remains neutral with regard to jurisdictional claims in published maps and institutional affiliations.

\section{Author details}

${ }^{1}$ Wuhan University School of Health Sciences, Wuhan, Hubei, China.

${ }^{2}$ Shandong University School of Public Health, Jinan, Shandong, China.

${ }^{3}$ Fudan University School of Medicine, Shanghai, China.

Received: 4 March 2018 Accepted: 15 May 2018

Published online: 29 May 2018

\section{References}

1. Han HJ, Wen HL, Zhou CM, Chen FF, Luo LM, Liu JW, et al. Bats as reservoirs of severe emerging infectious diseases. Virus Res. 2015;205:1-6.

2. Han HJ, Wen HL, Zhao L, Liu JW, Luo LM, Zhou CM, et al. Novel Bartonella species in insectivorous bats, northern China. PLoS One. 2017;12:e0167915.

3. Han $\mathrm{H}$-J, Wen H-L, Liu J-W, Qin X-R, Zhao M, Wang L-J, et al. Pathogenic Leptospira species in insectivorous bats, China, 2015. Emerg Infect Dis. 2018; 24. In press.

4. Schnittger L, Rodriguez AE, Florin-Christensen M, Morrison DA. Babesia: a world emerging. Infect Genet Evol. 2012:12:1788-809.

5. Marinkelle CJ. Babesia sp. in Colombian bats (Microchiroptera). J Wildlife Dis. 1996:32:534-5

6. Liu X, Yan B, Wang Q, Jiang M, Tu C, Chen C, et al. Babesia vesperuginis in common pipistrelle (Pipistrellus pipistrellus) and the bat soft tick Argas vespertilionis in Republic of China. J Wildlife Dis. 2018:54:419-21.

7. Corduneanu A, Hrazdilová K, Sándor AD, Matei IA, lonică AM, Barti L, et al. Babesia vesperuginis, a neglected piroplasmid: new host and geographical records, and phylogenetic relations. Parasit Vectors. 2017;10:598.

8. Gardner RA, Molyneux DH. Babesia vesperuginis: natural and experimental infections in British bats (Microchiroptera). Parasitology. 1987;95:461-9.

9. Concannon R, Wynn-Owen K, Simpson VR, Birtles RJ. Molecular characterization of haemoparasites infecting bats (Microchiroptera) in Cornwall, UK. Parasitology. 2005;131:489-96.

10. Hornok S, Estók P, Kováts D, Flaisz B, Takács N, Szőke K, et al. Screening of bat faeces for arthropod-borne apicomplexan protozoa: Babesia canis and Besnoitia besnoiti-like sequences from Chiroptera. Parasit Vectors. 2015;8:441.

11. Hornok S, Szőke K, Kováts D, Estók P, Görföl T, Boldogh SA, et al. DNA of Piroplasms of ruminants and dogs in ixodid bat ticks. PLoS One. 2016;11:e0167735

12. Walker $\mathrm{DH}$, Ismail $\mathrm{N}$. Emerging and re-emerging rickettsioses: endothelial cell infection and early disease events. Nat Rev Microbiol. 2008;6:375-86.

13. D'Auria SR, Camargo MC, Pacheco RC, Savani ES, Dias MA, da Rosa AR, et al. Serologic survey for rickettsiosis in bats from São Paulo city, Brazil. Vector Borne Zoonotic Dis. 2010;10:459-63.

14. Reeves WK, Streicker DG, Loftis AD, Dasch GA. Serologic survey of Eptesicus fuscus from Georgia, U.S.A. for Rickettsia and Borrelia and laboratory transmission of a Rickettsia by bat ticks. J Vector Ecol. 2006;31:386-9.

15. Dietrich M, Tjale MA, Weyer J, Kearney T, Seamark EC, Nel LH, et al. Diversity of Bartonella and Rickettsia spp. in bats and their blood-feeding ectoparasites from South Africa and Swaziland. PLoS One. 2016;11:e0152077.
16. Reeves WK, Beck J, Orlova MV, Daly JL, Pippin K, Revan F, et al. Ecology of bats, their ectoparasites, and associated pathogens on Saint Kitts Island. J Med Entomol. 2016.

17. Hornok S, Szőke K, Estók P, Krawczyk A, Haarsma AJ, Kováts D, et al. Assessing bat droppings and predatory bird pellets for vector-borne bacteria: molecular evidence of bat-associated Neorickettsia sp. in Europe. Antonie Van Leeuwenhoek. 2018. https://doi.org/10.1007/s10482-018-1043-7.

18. Piksa K, Stańczak J, Biernat B, Górz A, Nowak-Chmura M, Siuda K. Detection of Borrelia burgdorferi sensu lato and spotted fever group Rickettsiae in hard ticks (Acari, Ixodidae) parasitizing bats in Poland. Parasitol Res. 2016;115: 1727-31.

19. Sánchez-Montes S, Guzmán-Cornejo C, Martínez-Nájera Y, Becker I, Venzal JM, Labruna MB. Rickettsia lusitaniae associated with Ornithodoros yumatensis (Acari: Argasidae) from two caves in Yucatan, Mexico. Ticks Tick Borne Dis. 2016:7:1097-101.

20. Tahir D, Socolovschi C, Marié JL, Ganay G, Berenger JM, Bompar JM, et al. New Rickettsia species in soft ticks Ornithodoros hasei collected from bats in French Guiana. Ticks Tick Borne Dis. 2016;7:1089-96.

21. Socolovschi C, Kernif T, Raoult D, Parola P. Borrelia, Rickettsia, and Ehrlichia species in bat ticks, France, 2010. Emerg Infect Dis. 2012;18:1966-75.

22. Loftis AD, Gill JS, Schriefer ME, Levin ML, Eremeeva ME, Gilchrist MJ, et al. Detection of Rickettsia, Borrelia, and Bartonella in Carios kelleyi (Acari: Argasidae). J Med Entomol. 2005;42:473-80.

23. Wilkinson DA, Duron O, Cordonin C, Gomard Y, Ramasindrazana B, Mavingui $P$, et al. The bacteriome of bat flies (Nycteribiidae) from the Malagasy Region: a community shaped by host ecology, bacterial transmission mode, and host-vector specificity. Appl Environv Microb. 2016;82:1778-88.

24. Ben Said M, Belkahia H, Messadi L. Anaplasma spp. in North Africa: a review on molecular epidemiology, associated risk factors and genetic characteristics. Ticks Tick Borne Dis. 2018;9:543-55.

25. Colville JL, Berryhill DL. Q fever. Handbook of zoonoses. Saint Louis: Mosby; 2007. p. 139-41

26. Leulmi H, Aouadi A, Bitam I, Bessas A, Benakhla A, Raoult D, et al. Detection of Bartonella tamiae, Coxiella burnetii and rickettsiae in arthropods and tissues from wild and domestic animals in northeastern Algeria. Parasit Vectors. 2016;9:27

27. Linacre A, Lee JC. Species determination: the role and use of the cytochrome b gene. Meth Mole Biol. 2016;1420:287-96.

28. Kumar S, Stecher G, Tamura K. MEGA7: Molecular Evolutionary Genetics Analysis Version 7.0 for Bigger Datasets. Mol Biol Evol. 2016;33:1870-4.

29. Gardner RA, Molyneux DH, Stebbings RE. Studies on the prevalence of hematozoa of British bats. Mammal Rev. 1987;17:75-80.

30. Socolovschi C, Mediannikov O, Sokhna C, Tall A, Diatta G, Bassene H, et al. Rickettsia felis-associated uneruptive fever, Senegal. Emerg Infect Dis. 2010; 16:1140-2.

31. Kang JG, Ko S, Kim YJ, Yang HJ, Lee H, Shin NS, et al. New genetic variants of Anaplasma phagocytophilum and Anaplasma bovis from Korean wate deer (Hydropotes inermis argyropus). Vector Borne Zoonotic Dis. 2011;11: 929-38.

32. Liu L, Baoliang $X$, Yingqun $F$, Ming $L, Y u Y$, Yong $H$, et al. Coxiella burnetii in rodents on Heixiazi Island at the Sino-Russian border. Am J Trop Med Hyg 2013:88:770-3.

\section{Ready to submit your research? Choose BMC and benefit from}

- fast, convenient online submission

- thorough peer review by experienced researchers in your field

- rapid publication on acceptance

- support for research data, including large and complex data types

- gold Open Access which fosters wider collaboration and increased citations

- maximum visibility for your research: over $100 \mathrm{M}$ website views per year

\section{At BMC, research is always in progress.}

Learn more biomedcentral.com/submissions 